\title{
ECONOMIC SECURITY AND PRINCIPLES OF SELF-ORGANIZATION: CHINA'S EXPERIENCE
}

\author{
Tatiana Yegorova-Gudkova ${ }^{1}$, Panj $^{L^{2}}{ }^{2}$ \\ ${ }^{1}$ Ph.D. (Economics), Associate Professor, Associate Professor of Economic-Law Department, Odessa Mechnikov's \\ National University, Odessa, Ukraine, e-mail: tatiana_yeg@rambler.ru, ORCID: https://orcid.org/0000-0001-7869- \\ 8777 \\ ${ }^{2}$ Magister's Student of Economic-Law Department, Odessa Mechnikov's National University, Odessa, Ukraine
}

\section{Citation:}

Yegorova-Gudkova, T., \& Li, P. (2020). Economic security and principles of self-organization: China's experience. Economics, Finance and Management Review, (2), 43-53. https://doi.org/10.36690/2674-52082020-2-43

Received: April 15, 2020 Approved: May 21, 2020

Published: June 05, 2020

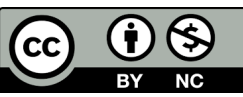

This article is an open access article distributed under the terms and conditions of the Creative Commons Attribution (CC BY-NC 4.0) license

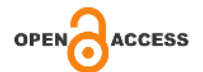

\begin{abstract}
The article proposes to analyze the theme of self-organization of China's economy and examining the issues of security of the economy of the state from the point of view of the systematic and self-organizational approaches. The main scientific tried to explaining the reasons for the growth of the shadow economy. $R$. Coase and his followers, the shadowing of the economy is linked to the costs of using the market mechanism or transactional costs.. H.de Soto. the main reason for the emergence of mass shadow economic activity should be considered to be an inefficient legal regime, not the "failures of the market" but the "failures of the state" are the main threat to the national economy. Tries to consider the mechanism of self-organizational development for ensuring economic security, which is a complex concept that presupposes the protection of the most important elements of the economic system and self-sufficiency in the occurrence of destabilizing internal and external factors that threaten it, rhythm of it's functioning. Investigation of security issues of the state's economy should be based on transdisciplinary approach and use Nature's like models. Also it should be methods of theory of system and theory of synergetic considered on the mechanism of self-organizational. The economic system must be open, nonequilibrium, nonlinear and emergent. Nonlinearity describes its behavior by nonlinear multifactor equations, with small changes in the system parameters its state and properties change abruptly. Accordingly, first, the formulation of a diversified structure of energy imports, and second, the development, improvement and implementation of energy-saving technologies domestically.
\end{abstract}

The cybernetic approach of self-organization dominates the Chinese economy, state intervention is actively present in economic relations, sometimes overregulation in one area and under-regulation in the other sphere adversely affect the stability of the economic system. Designing of the system of economic security of the state (as a special case of designing a sustainable system based on the principles of self-organization) we should comply with the law of structural harmony of the systems, the attractor of the golden ratio or be carried out on the basis of a recursive series of golden sections: $0.618 \ldots$..; $0.682 \ldots$..; 0.725 ...; 0.755 ... 1.0 as the nodes of the measure and involves the transitions of integrated measures of system from one node to another.

Keywords: economic security of state, transdisciplinary approach, selforganization, China's economy, law of measure or golden section and its derrivatives.

JEL Classification: B41, C19, $\mathrm{H56}$

Formulas: 0; fig.: 10; tabl.: 0; bibl.: 17

Introduction. Creating economic security is one of the most important national priorities of any country. The concept of economic security has an alternative to the concept of economic threats, to which economic crime directly relates. Economic crime arises under conditions of being able to compete with the legal economy in the production of the most profitable goods and services and reflects the disadvantages of the legal economy.

The experience of transformational economies shows that organized crime has intensified since the beginning of the transformation. One of the mechanisms of 
survival and development of economic crime is corruption, through which economic crime penetrates public and public authorities. The algorithm of interaction between governmental organizations and organized crime is the basis of conflict of interest and is to provide its parameters for each of the parties to the conflict. The expertise of the Western powers and domestic experience in combating economic crime shows that only criminal justice measures are insufficient in the current context. Thus, the relevance of the search for new ideas in order to create conditions for economic security becomes a priority area of state economic policy. In this aspect, the idea of designing economic security, its security measures and the impact on economic crime is a necessary requirement of the present time.

Economic security is the ability and opportunity for a country's economy to develop in the face of conflict, uncertainty, and risks regarding the conditions of existing reality. From the point of view of classification on external and internal factors - the necessary level of economic security of the country can be provided first of all by internal systemic factors that shape its integrity and adaptability to changes [1].

The tasks of creating a security environment for a country are based on its national interests. At the same time, the main national interests include "foreign policy interests of the state related to ensuring its security and integrity as a determined socio-economic, political, national-historical and cultural community, with protection of the economic and political independence of the state", incl. the core is the notion of integrity, independence and security.

The task of ensuring the necessary level of economic security is multilevel. At least three levels can be distinguished - the individual, the state and the world economic system. According to the conditions of a particular country, it has the levels of enterprises (firms), industry, region of the country and so on.

The concepts of economic security threat must also be structured accordingly:

- threats to the economic security of citizens;

- security threats to the market subsystem;

- security threats to the subsystem of the state.

Thus, the economic security of the country has three components, which are the subjects of economic security. Identifying the nature of the threats posed by an economic security issue is key to defining the very concept of economic security. The threat results from the destruction of the object or damage to the object [2].

Threats can have different sources of origin, for example, the relationship of countries in the field of international economic relations, the spontaneous impact of the world economy; internal crises and imbalances.

Literature Review. In understanding national economic security issues, the most important concept proposed by new institutionalists is related to the problems of the shadow economy. The main scientific discovery is a fundamentally new approach to explaining the reasons for the growth of the shadow economy. According to the work of R. Coase and his followers, the shadowing of the economy is linked to the costs that the new institutionalists call transactional. The doctrine of transaction costs in the new institutional economy is fundamental, fundamental and important. New 
institutionalists believe that it is important to take into account not only the costs of human interaction with nature (ie, transformational ones), but also the costs of using a market mechanism [4;7]. It is in order to avoid high transaction costs that the process of forming the shadow sector of the economy begins.

Let us analyze the system of economic security of China and the ways of providing it from the standpoint of self-organization methodology. Chinese scientist Zhang Yong gave a brief definition of "economic security": "For developing countries such as China, economic security is best defined as the ability to ensure a gradual rise in the living standards of the entire population through national economic development while maintaining economic independence [5; 13].

So, to understand the problems of national economic security is assumed the concept of a shadow economy, its representative - Peruvian economist Hernando de Soto. In his view, the main reason for the emergence of mass shadow economic activity should be considered to be an inefficient legal regime, when the prosperity of the enterprise depends more and less on the effectiveness of the legal regime and the legal costs imposed on it. An entrepreneur who is more successful is the one who is better at manipulating ties with officials, that is, the shadow sector.

Therefore, not the "failures of the market" but the "failures of the state" are the main threat to the national economy $[6 ; 7]$.

Thus, for the more developed countries in the modern world, the most relevant approach is D.M. Keynes, where active state regulation will play a role as an assistant to the "free hand", for others, including China, the approach of new institutionalism and E. de Soto, where on the one hand the market procedure should be made "transparent", on the other hand, the free market participants should observe the rule of conduct so as not to increase transaction costs and thus to reduce efficiency.

The system of economic security includes: technological and industrial security, financial security, energy security, food security, environmental security, information security, etc. The following is a detailed description of the organizational structure of economic security, and an analysis of its constituent elements that will be directly addressed by us in this article:

1. Technological and industrial safety. In the broad sense, it is explored as the ability of the industry of the country in the event of a breach of external relations with other countries (sources of production of raw materials and fuel for the production and marketing of finished products) of the world or the emergence of internal socioeconomic shocks to quickly neutralize and compensate for their negative consequences, to sustainably expand the process reproduction, thus meeting public needs. It is closely linked to both material and social factors of production. In the narrow - the state of competitive industrial capacity of the national economy, and the position of domestic goods and services in the world markets, due to the scientific and technical potential of the country.

2. Financial security. Financial security refers to the state of financial institutions, the harmonious development of a set of financial relationships and processes, which ensures full protection of economic systems. This is the most important element and factor of economic security, which determine the state of 
sustainable development of the country's financial system and the ability to withstand external threats.

The importance of financial security is also due to the fact that in the $21 \mathrm{st}$ century, confrontation and struggle between states are represented in the form of a "war without gunpowder", the peculiarity of which is that, as a measure of expressing the intention to protect national interests and plus claims against new ones, not by introducing traditional combat methods and actions, but by unconventional ones, such as information, economic, financial, which at times prove more destructive.

From the standpoint of this approach, the main criterion for war is not the means, but the results achieved, comparable to those usually expected in the event of a victorious end to a traditional war [9].

3 . Food security, assumes that the economy of the country is provided with food in the amounts necessary for the effective functioning of the national economy. Food security must ensure the sustainable production of basic foodstuffs and their accessibility to the public. At the heart of food security is the realization of the capacity and capacity of their own provision (physical and economic availability), the reservation of a certain proportion of food stocks by purchasing on the world market (physical and economic availability), and most importantly - the quality of food resources.

4. Energy security. In the energy component of the economic security of the state, it is envisaged to ensure the stability of physical supplies of energy resources for domestic consumption, and the ability of the national economy to adapt to an unforeseen increase in world prices for them, or in the worst case, self-sufficiency within a certain period.

Aims. The aims of this article are to consider the tramsdisciplinary approach, Law of Measure as Golden Section and its derivatives and the main - mechanism of self-organizational development for ensuring economic security, which is a complex concept that presupposes the protection of the most important elements of the economic system and self-sufficiency in the occurrence of destabilizing internal and external factors that threaten it, rhythm of it's functioning..

According to above we intend to investigate the system of economic security and its structural parts: technological and industrial security, financial security, energy security, food security, environmental security, information security, etc. The following is a detailed description of the organizational structure of economic security, and an analysis of its constituent elements that will be directly addressed by us in this article:

Methods. Due to the fact that until recently, much attention was paid to the science of natural sciences, based on mechanical and mathematical views, in the field of socio-economic research was also dominated mainly by the classical methodology, characterized by a deterministic causal relationship between the factor of the event and its result.

However, this view is currently undergoing a systemic crisis. For example, the principle of perfect equilibrium is based on the general theory of economics, but this 
does not always happen. In areas such as financial markets, monetary circulation and credit, economic systems can remain unbalanced indefinitely.

Thus, the interpretation of the economic security of the state requires the application of a new view, to which the theory of self-organization, which proposes to carry out research taking into account the chaotic, nonlinearity of the system, is relevant.

The authors confines to the study of security issues of the state's economy from the point of view of a systematic approach, attempts to consider the mechanism of self-organizational development for economic security, which is a complex concept that presupposes the protection of the most important elements of the economic system and self-sufficiency in the occurrence of destabilizing internal and external factors-threatening its normal rhythm of functioning [3].

Results. The economic system must be open, non-equilibrium, nonlinear and emergent. Nonlinearity describes its behavior by nonlinear multifactor equations, with small changes in the system parameters its state and properties change abruptly.

Accordingly, first, the formulation of a diversified structure of energy imports, and second, the development, improvement and implementation of energy-saving technologies domestically. The solution to this problem at the state level is quite urgent as it gives the opportunity to prevent threats related to energy deficiency in the national economy. The openness and disequilibrium of China's technological production system are reflected in the economic dependence of the sectoral and sectoral structure of the economy. Consider the sectoral structure of China's economy and are reflected in the indicator of economic dependence and sectoral structure of the economy. China's economic dependence is usually calculated in the form of a factor, which is the ratio of the amount of imports and exports to the amount of GDP in monetary terms over the observed periods. The sectorial structure of the economy and its relationship with the stage of socio-economic development: each country of the world goes through three stages of development: agrarian, industrial and postindustrial stage. We present the data in Figures 1-6.

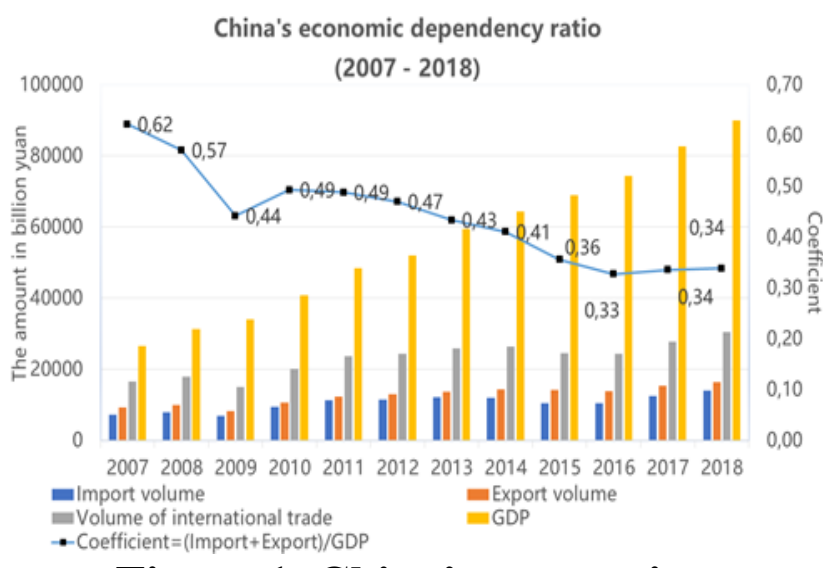

Figure 1. China's economic dependency ratio composition (2007-2018)

Source: developed by $[10,13,14,15,16]$
China's GDP sector composition (2006 - 2018)

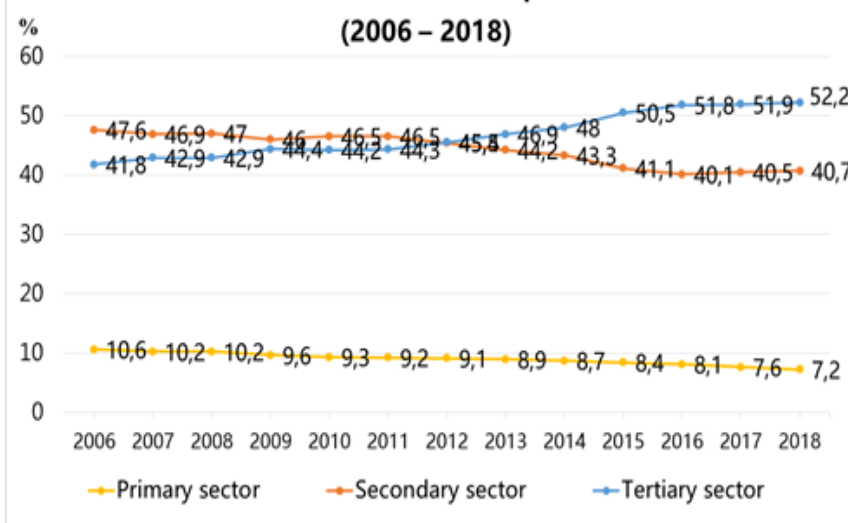

Figure 2. China's GDP sector (2006 - 2018) 


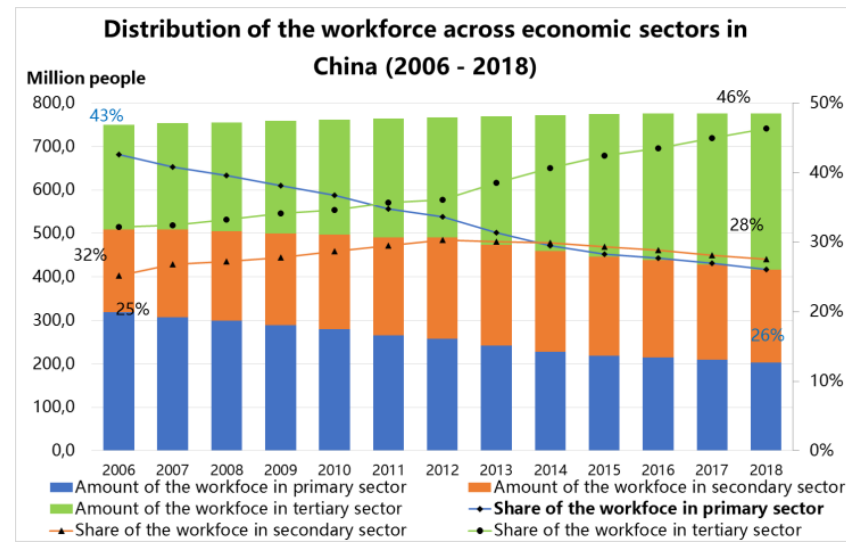

Figure 3. Distribution of the workforce across economic sector in China (2006-2008)

Source: developed by [10, 13,14, 15.16]

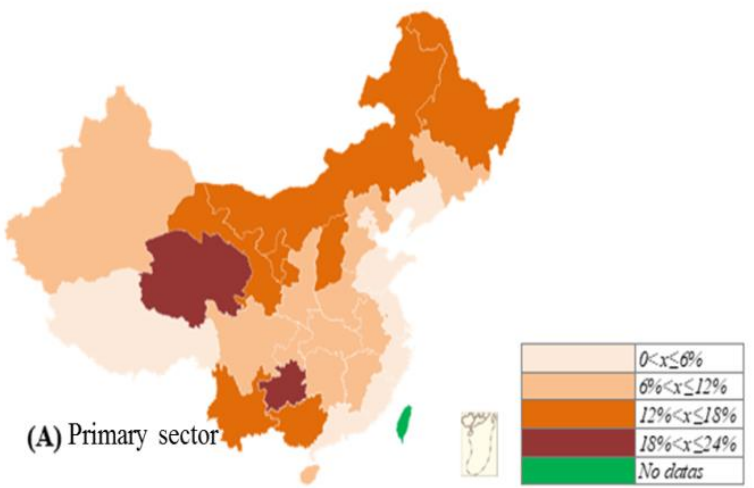

Figure 4. Adverse conditions for the development of the $2^{\text {nd }}$ and $3^{\text {rd }}$ sector of the economy; one of the poorest region of the country

Source: developed by [10, 13,14, 15.16]

Distribution of legal entities across economic sectors among different provinces and regions:

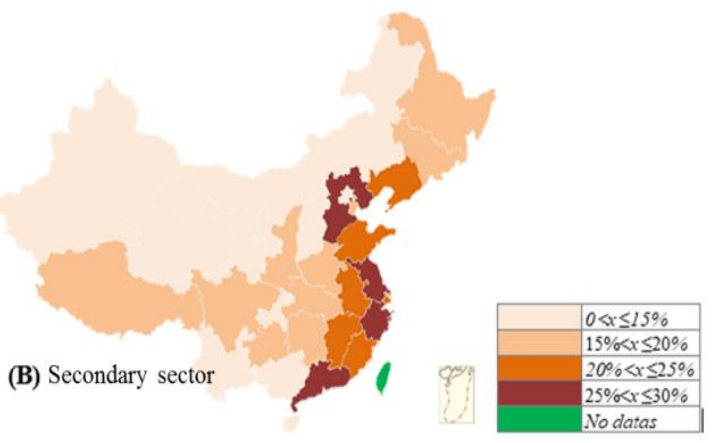

Figure 5. Distribution of legal entities across secondary economic sectors among different provinces and regions

Source: developed by [10, 13,14, 15.16]

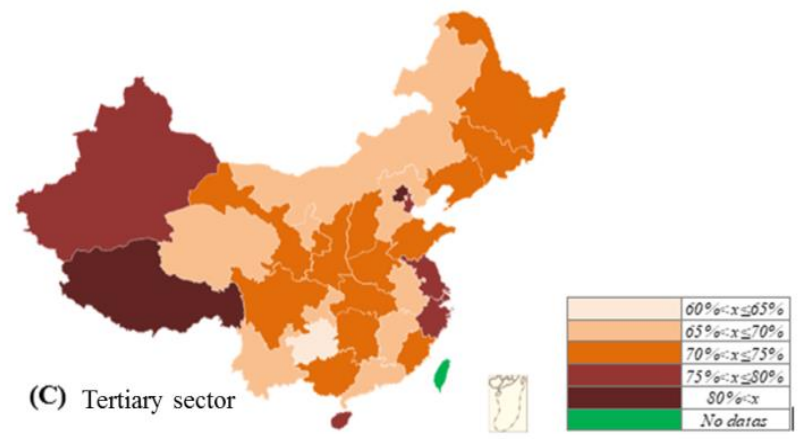

Figure 6. Distribution of legal entities across tertiary economic sectors among different provinces and regions

Source: developed by $[10,13,14,15.16]$

The technological and production component of economic security is determined by the state of the scientific and technical potential of the state's production capacity, which guarantees the competitiveness of the goods and services of national enterprises in the world market, as well as ensures independent development in the shortest possible time of innovations and innovations, on the basis of a rational and effective sectoral structure.

Having achieved technological and industrial security, the state, as a rule, has the ability of the national economy to worsen foreign economic or internal socioeconomic situations to quickly compensate for their negative consequences, to sustainably provide extended reproduction, and thus meet public needs.

The financial component. State of the financial, including monetary, banking, monetary, fiscal, and other systems characterized by resistance to internal and external negative influences. 
From the standpoint of self-organization theory, it creates the conditions for the emergence of an attractor in the financial system, near which the internal structuring, stabilizing factors hold up over the destructive and destabilizing factors.

The study of China's financial security in this paper will be seen from the perspective of the shadow banking sector. These are financial institutions that provide the same range of services as banks, but for some reason are not subject to banking regulation by government agencies.

The problem with the peer-to-peer lending platform (Peer-to-Peer P2P Loan) in China is particularly complicating its financial sustainability.

Possible reasons include tight financial constraints and inflation. Is a way to lend money to unrelated persons or parties without the involvement of a traditional financial intermediary; loans are provided online on the websites of special credit institutions.

A negative example is the scandal with the largest platform of the time, Ezubao, which turned out to be a financial pyramid and, with the help of the latter, was summed up by the company a sum of money of $\$ 7.3$ billion at 900 thousand. investors in 2017.

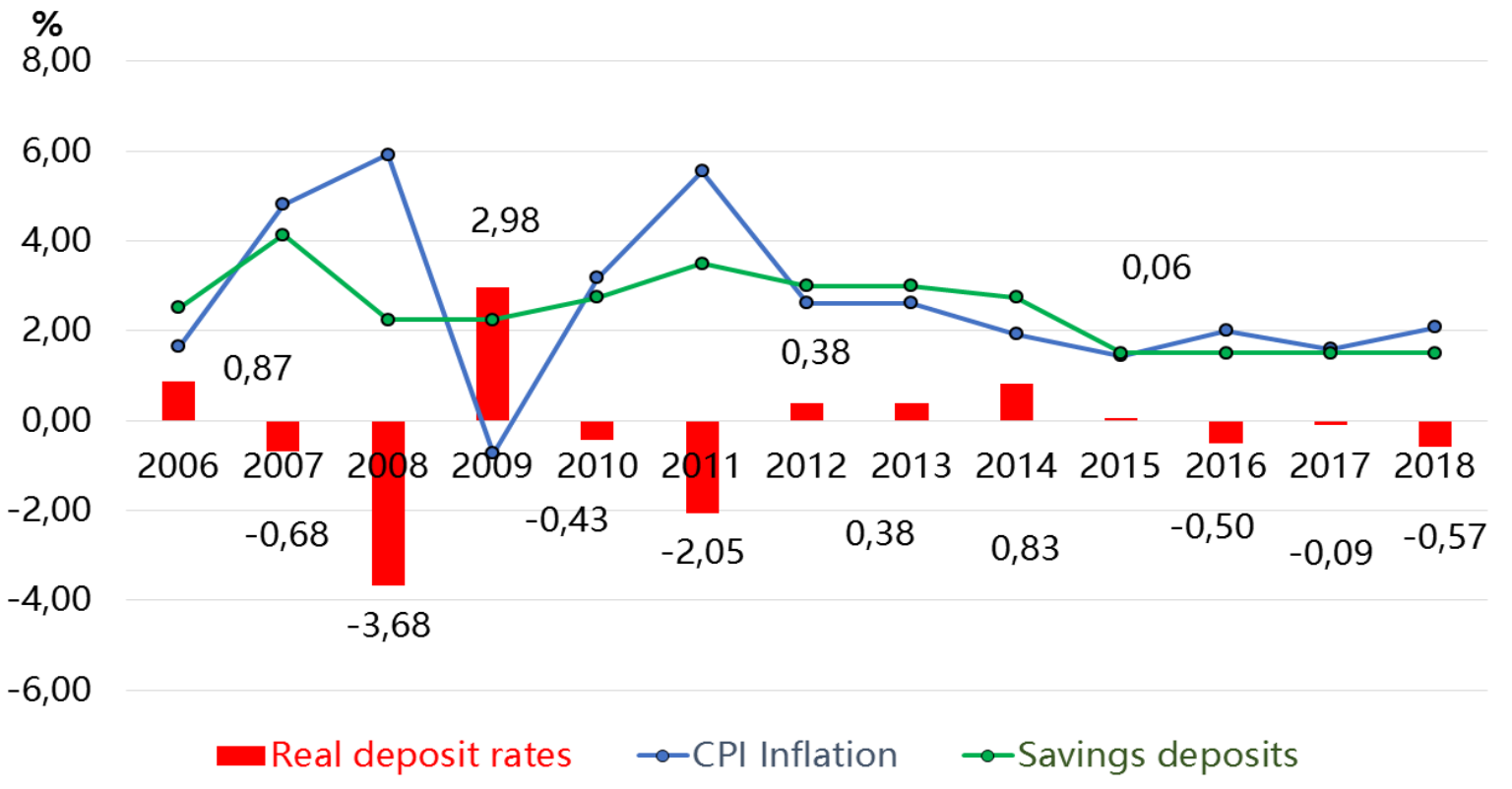

Figure 7. Real deposit rate and CPI Inflation of China (2006 - 2018) Source: developed by [10, 13, 14, 15, 16]

Food and energy security. Physical accessibility, affordability and quality of food production. Self-sufficiency, quantity of domestic production, quantity of production per unit area ( $\mathrm{kg} /$ hectare), structure of food consumption, area of arable land, level of mechanization of agricultural, etc.

The White Paper of the State Council of the Government of the People's Republic of China "China's Food Security" writes that "from a medium and long-term perspective, China's need to increase food production remains at an intense high level."

"The question of China's food security has always been, is, and will forever be the sword of Damocles over the Chinese people's head" [16]. 


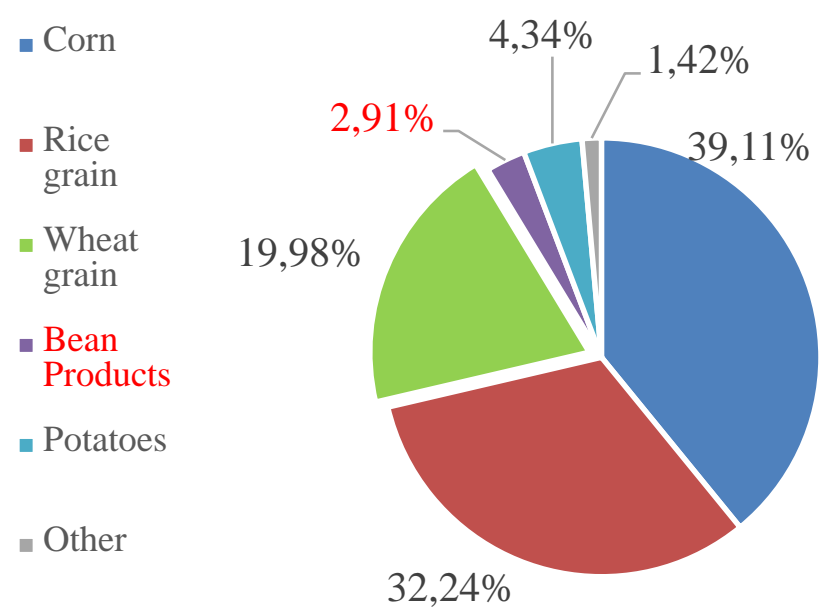

Figure 8. China's food production structure in 2018

Source: developed by $[10,13,14,15,16]$
$150 \quad$ Food import structure of China in 2018

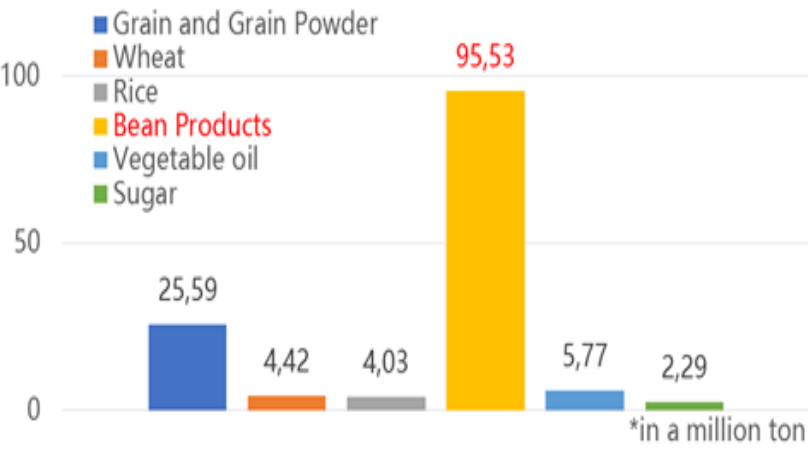

Figure 9. Food import structure of China in 2018

Source: developed by [10, 13,14, 15, 16]

1.The dependence of Chinese legumes on foreign supplies exceeds $80 \%$. The huge need for legumes as feed materials, which is a necessary product for the development of livestock.

2. In turn, the need for China's livestock development is determined by the rapidly increasing need for meat products. Impact of the trade war with the US rising prices for legumes - rising prices for meat - rising prices for other products.

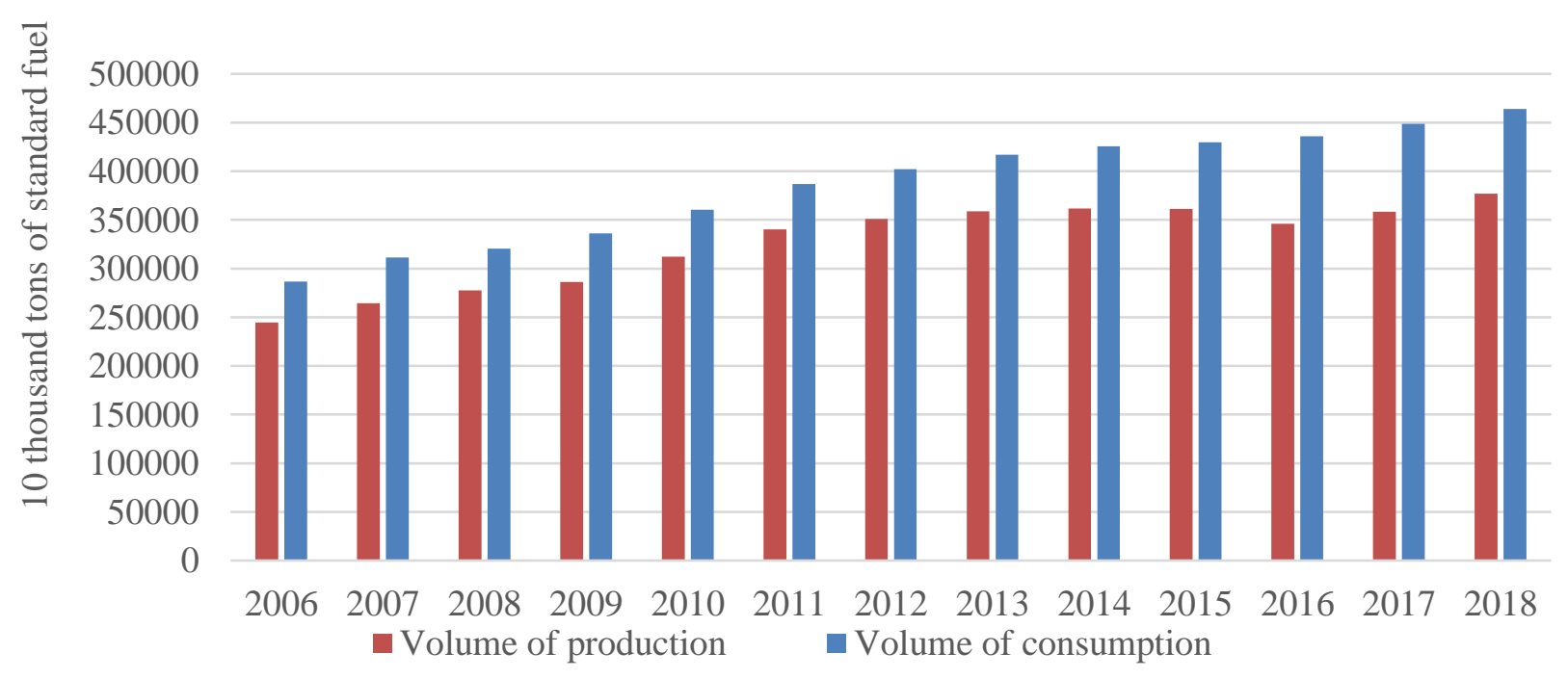

Figure 10. Quantity of energy production \& consumption of China (2006 - 2018) Source: developed by [10, 13, 14, 15, 16]

Energy security threats are events that could adversely affect the physical and economic availability of energy resources and the level of their efficiency.

There is a large imbalance between China's domestic production and energy consumption, which is characterized by a shortage of energy resources and a high dependence of these resources on other countries. 
Discussion. Due to the globalization of the world economic crisis and other problems of humanity's civilization, scientists have to revise the proposed and developed theories, and even more so to gradually adopt the ideas of nonlinearity of socio-economic sciences, and move on to a new direction of their development. The latest achievement in this field is the work of American economist Richard Thaler, who was awarded the 2017 Nobel Prize in Economics for his contribution to the study of behavioral economics. His scientific work examines the influence of social and emotional factors on economic decision-making by individuals and institutions, and the impact of this influence on markets.

The current state of traditional economic theory is characterized by many wellknown researchers as a systemic crisis: "Thanks to the mathematization of economic theory, it has produced a number of general results that actually indicate the incompleteness or inadequacy of axiomatics of underlying models, which entails the lack of answers to the most important questions" [12].

It is the understanding that the economy as a dynamic and complex system is not always in a state of equilibrium, the complexity of its objects and the causes of the crisis in it are insufficiently studied that market participants in the general case do not fit the ideal and rational model of economic behavior and equilibrium served as a prerequisite and the starting point of applying the theory of self-organization as a new paradigm for the interpretation of economic science. The general theory of systems and the theory of self-organization, common to which the systematic approach stands, represent one of the directions of the modern sciences and are oriented to the discovery of new theoretical knowledge with the idea of holistic, system objects.

The Road to Economic Self-Organization: Practice in China. Reform and openness: towards the concept and recognition of the complexity, openness and nonlinearity of the economic system. The recognition by political conservatives of the effectiveness of the market mechanism was expressed by the process of knowing the complexity, openness and non-linearity of the economic system;

The first step of the reform took place in agriculture, and the transition to a "household contract liability system", which gave responsibility for agricultural production to individual households, was completed. Prior to this, the authorities did not allow the peasants to enter into economic activity on their own. The impetus for the development of this system is the signing of a secret contract by 18 peasants with local staff in 1978 on the independent distribution of land to farmers for agriculture. Symptoms of self-organization Special Economic Zone (since 1980), TechnoEconomic Development Zone (since 1984), Open Economic Zone (since 1985), Free Trade Zone (since 2013), and Cluster: Effect of Synergy and Self-Management. Together with the reform process in the agrarian sector, the attention of state institutions turned to the transformation of the industry. However, due to the lack of liberal economic policies (including monetary and credit policies), the planned free trade area (2013) in Shanghai has not reached its intended goals.

The economic characteristics of special economic zones are presented in the form of the following principles:

- Attraction and use of foreign capital; 
- Development of joint venture Chinese-foreign capital, as well as fully foreignowned company;

- Production in these areas is primarily export oriented;

- Relatively liberal economic policies, preferential investment and credit conditions.

Conclusions. The cybernetic approach of self-organization dominates the Chinese economy, state intervention is actively present in economic relations, sometimes over-regulation in one area and under-regulation in the other sphere adversely affect the stability of the economic system $[15 ; 16]$.

The analysis of statistical data, charts and heat maps (cartography) shows the structural risk of China's economic security, the role of state coordination and assistance in the development of stabilizing economy factors to shape the conditions for self-organization.

Designing of the system of economic security of the state (as a special case of designing a sustainable system based on the principles of self-organization) we should comply with the law of structural harmony of the systems, the attractor of the golden ratio or be carried out on the basis of a recursive series of golden sections: $0.618 \ldots ; 0.682 \ldots ; 0.725 \ldots ; 0.755 \ldots \ldots . . .1 .0$ as the nodes of the measure and involves the transitions of integrated measures of system from one node to another $[8 ; 12]$.

The components of the design methodology for a holistic, sustainable and selforganizing economic system of economic security based on Law of Measure are following:

1. Assessment of the status of the economic system (for example, the state economic security system).

2. Assessment of the structural and functional state of the system.

3. Assessment of the level of vertical business integration by industry and economic sectors;

4. Assessment of the level of banking up to coenose's approach

5. Assessment of the share of value added in GDP;

6. Comparison of the evaluation results with attractors representing a recursive series of golden sections: $0.500 \ldots ; 0.618 \ldots ; 0.682 \ldots ; 0.725$.

7. Monitoring the reliability and viability of the system.

8. Investigation of the problem of system redundancy.

9. Entropy testing of the system (calculation of information entropy)

10. Formulation of the project restructuring (reengineering) system

11. Implementation of the project.

12. Assessment of the designed system for structural and functional correspondence to the golden section attractors $[11 ; 12]$.

The more proportions of the Golden Section and its derivatives will be contained by the projected system, the higher will be its level of self-organization and stability in the conditions of external and internal disturbances.

Moreover, it will comply with Natural systems and principles of Nature like management. 


\section{Authors contributions. The authors contributed equally. Disclosure statement. The authors do not have any conflict of interest. References:}

1. Orlova A.V. (2012).Evolution of the concept of "Economic security". Scientific Bulletin of the Belgorod State University. Series: Economics. Informatics. p. 138.

2. Nikitenko P.G., Bulavko V.G. (2009). Economic security: theory, methodology, practice // Institute of Economics of NAS of Belarus. Minsk: Law and Economy pp. 14-15.

3. Bertalanffy L. Von (1969) Research on General Systems Theory: Sat. translations. pp. 23 - 82.

4. Nikolis G., Prigogine I. (1979). Self-organization in nonequilibrium systems: From dissipative structures to ordering through fluctuations. pp. $71-72$.

5. Special economic zone: Chinese economics. Encyclopaedia Britannica (2019). Retrieved from: https://www.britannica.com/topic/special-economic-zone

6. Institutionalism: Neoinstitutionalism. [Electronic resource] // IE: Institutional economy. 2019. Retrieved from: http://institutional.narod.ru/history $1 / \mathrm{ch} 8 . \mathrm{htm}$

7. Ernando del Soto. The other way. Invisible Revolution in the Third World T. Translated by "Catallaxy" Publishing House. (1995) from:: http://www.vixri.com/d/Ernando\%20de\%20Soto\%20_INOJ\%20PUT'\%20Nevidimaja\%20revoljucija\%20v\% 20t.pdf (Accessed 3 May 2019).

8. Soroko E.M. (2018). Golden sections. The processes of self-organization and evolution of systems. $234 \mathrm{p}$.

9. Leader of China's \$9 billion Ezubao online scam gets life; 26 jailed. REUTERS: World News (2017).

Retrieved from: https://www.reuters.com/article/us-china-fraud/leader-of-chinas-9-billion-ezubao-onlinescam-gets-life-26-jailed-idUSKCN1BN0J6

10.China freezes assets of more than 380 companies in the sphere of $\mathrm{p} 2 \mathrm{p}$-lending for $\$ 1.5$ billion. NEWS Economy. (2018) Retrieved from: https://www.vestifinance.ru/articles/114899

11.Yegorova-Gudkova T.I., Krygin A.S., Boyko M.V. (2018) Economic security of the state: the influence of fundamental factors and development priorities. Market Economy: Modern Management Theory and Practice. Retrieved from: http://dspace.onu.edu.ua:8080/handle/123456789/20499

12. Yegorova-Gudkova T.I. (2017) Some proportions of the economic system of the state in the conditions of developing a strategy for solving the crisis. (Velyko Tyrnovo, March. 2016): Scientific proceedings of the Scientific Technical Union of Mechanical Engineering p. 61-64.

13.Ehlers T., Kong S., Zhu F. (2018). Mapping shadow banking in China: structure and dynamics. p. 27.

14.. State Council of China: China's food security (2019) Retrieved from: http://www.gov.cn/zhengce/201910/14/content_5439410.htm

15.. China Agricultural Information: The difference in agricultural development between China and the US. (2017). Retrieved from: http://www.agri.cn/V20/SC/jjps/201705/t20170519_5615220.htm

16.. Report of the Secretary-General of the United Nations "Energy and Transport" Retrieved from: http:// www.un.org.

17. Akhromeeva T.S., Kurdyumov S.P., Malinetskii G.G., Samarskii A.A. (1992). Non-stationary structures and diffusion chaos. p. 544. 